\title{
CONSIDERATIONS ON FORMATION AND TRANSFORMATION OF HOUSE TYPES IN THE OLD QUARTER OF CADIZ
}

\author{
カディス旧市街の住宅類型の形成と変容に関する考察
}

\author{
Juan Ramon JIMENEZ VERDEJO*, Jesús Alberto PULIDO ARCAS ** and Shuji FUNO*** \\ J.R. ヒメネスベルデホ, J.A. プリドアルカス，布野修司
}

\begin{abstract}
This paper aims at clarifying the process of formation and transformation of house types in San Francisco area, in the old quarter of Cadiz. Authors did intensive fieldwork in the year 2009 to investigate the current condition of extant buildings, compiling a database for 83 heritage properties registered as architectural heritage by the local authorities. Historical records and planning documents have been used to trace back the origins of these types and their transformation through a time span of 400 years based on the fieldwork on their current situation. As a result, these types can be understood with respect to their main elements pertaining building morphology.
\end{abstract}

Keywords : Cadiz, San Francisco district, house type, historical cultural heritage, transformation process カディス，サン フランシスコ地区，住居類型，歴史文化遺産，変容過程

1. Introduction.

1-1 Objectives.

The targeted district named San Francisco covers around $68.000 \mathrm{~m}^{2}$ in the Northwest area of old quarter of Cadiz, which is registered as no.9 within 12 districts designated as cultural heritage. The district comprises 22 blocks and 224 buildings, 88 of which are listed in inventory of architectural heritage by local municipal heritage board.

House types in Cadiz have been previously studied by several authors $1,2,3,3,4,5) 66$, focusing on stylistic features, but this paper discusses the current state of extant heritage residential buildings in terms of building morphology.

The objective of this paper is to classify the spatial formation of residential buildings according to variables related to building morphology and to clarify the formation and transformation process of building types.

\section{1-2 Materials and methodology.}

Fieldwork was conducted from January to November in 2009. The outcome constituted the material for a database compiled in MS Access ${ }^{\circledR}$, and in PDF data reference sheets for each assessed property ${ }^{7)}$. Planning documents from the municipality of Cadiz can be used including CAD, GIS files and statistical records to crosscheck surveyed data. Cadastral database is provided by the Spanish Ministry of Finance, with detailed description of the property division of buildings, as well as their uses ${ }^{8}$.

Process of transformation has been traced back by means of MAC (Municipal archives of Cadiz) ${ }^{0}$ featuring a database of 4.935 original drawings of historic building plans (Fig. 3) and urban areas 9), and also digital archives, such as AGS 10) (Archivo General de Simancas) and ICC 11) (Institut Cartographic de Catalunya), which contains historical plans and views. Additional materials are helpful to make a reconstruction of the origin of house types. Historical records including data about property structure 12) and historical reviews analyses house types in Cadiz supply with complementary data for the present research ${ }^{13), 14), 15), 16), 17)}$.

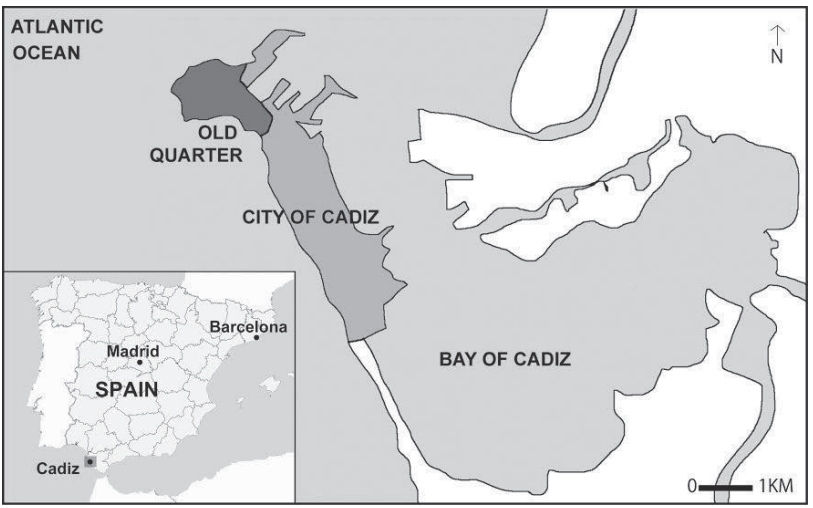

Fig. 1 Location of the city of Cadiz within Spain

* Assoc. Prof., Graduate School of environmental planning, University of Shiga Prefecture, Ph.D.

* Canon Foundation Fellow

Visiting Researcher, University of Shiga Prefecture, Ph.D.

*** Nihon University Research Prof., Dr.Eng.

滋賀県立大学環境料研究料 淮教授 ·博士 (芸術工学)

キャノン財団研究員

滋賀県立大学 客員研究員・博士

日本大学 特任教授.丁博 


\section{1-3 Fieldwork.}

The location of 83 residential properties ${ }^{i}$ surveyed is shown in Fig. 2. The database includes 83 house plans, 83 locations plans and 1.320 photographs.

The address, numbers of floors, the size and area of the plot, the area of building etc. of surveyed properties are summarized in Table 1.

\section{Classification of House Types.}

The 83 surveyed buildings were classified according to the following categories (fig. 4).

$\mathrm{X}$-axis is divided according to the number of plot frontages, and subdivided in terms of number of spans in the main frontage; for plots with 2 fronts, only the spans of the main façade are considered for classification, that is, the number of entrances through where the building can be accessed, which is important for the spatial formation.

Y-axis is divided primarily into number of spans inwards, and subdivided according to number of patios (void spaces inside the plot), as they are important elements in building morphology.

Based on these categories in terms of $\mathrm{X}$ and Y-axes, buildings are classified into 3 main groups with their subdivisions.

The majority of buildings (58) have 3 spans in front, which would correspond to types B (1 frontage) and C (2 frontages). These 3 types are summed up to 72 out of 83 properties surveyed, which account for a percentage of $86.7 \%$.

Type A comprises 14 buildings with 1-frontage plot with 2 spans in front, and it is subdivided into two, A1 and A2; These two types have $2+$ patios, A1: IV spans in the Y-axis ( 7 items), A2: $\mathrm{V}+$ spans $(7$ items).

Type B with 3 spans in front is subdivided into subtypes B1, B2 and B3 according to the number of spans in depth, and patios. Subtype B1, 3 spans in depth, includes properties with 1 patio (9 items), and two patios (4 items). Subtype B2, which has 4 spans in depth, has mainly properties with $2+$ patios (12 items) at the expense of those ones with one patio ( 2 items). Subtype B3, plots with $\mathrm{V}+$ spans in depth, only includes properties with 2 patios (5 items).

Globally, type C follows the same pattern as type B, but faces two frontages; subtype $\mathrm{C} 1$, plots with 3 spans in depth, includes properties with one patio (8 items) and $2+$ patios (5 items); subtype C2, plots with 4 spans in depth, includes 1 patio (4 items) and $2+$ patios (9 items).

\section{Statistical analysis.}

Following on the classification above, 3 types are analysed with respect to the following variables pertaining building morphology.

Numerical parameters are shown in Table 2: Plot area $\left(\mathrm{m}^{2}\right)$, built area $\left(\mathrm{m}^{2}\right)$, plot occupancy $(\%)$, floor area ratio FAR $\left(\mathrm{m}^{2}\right.$

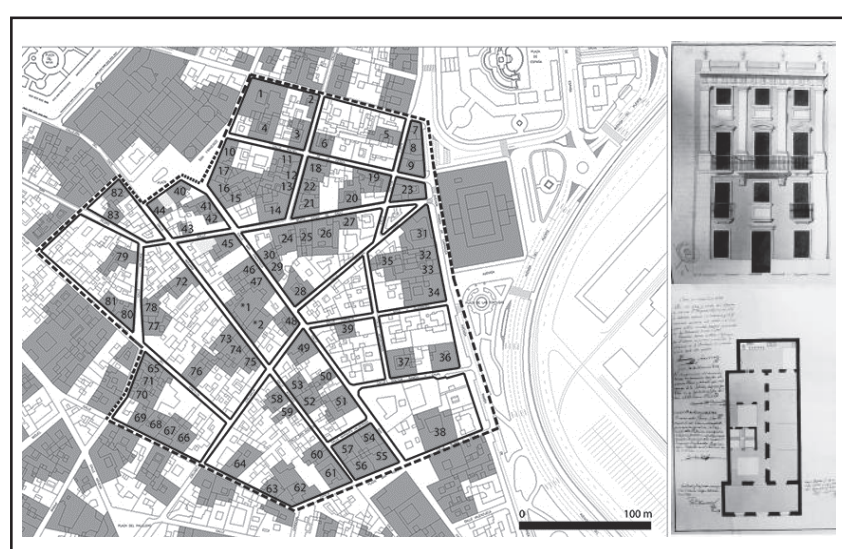

Fig. 2 Fieldwork area. Fig. 3 Historical plan. MAC p.745 812-934 Table 1 Fieldwork database resume.

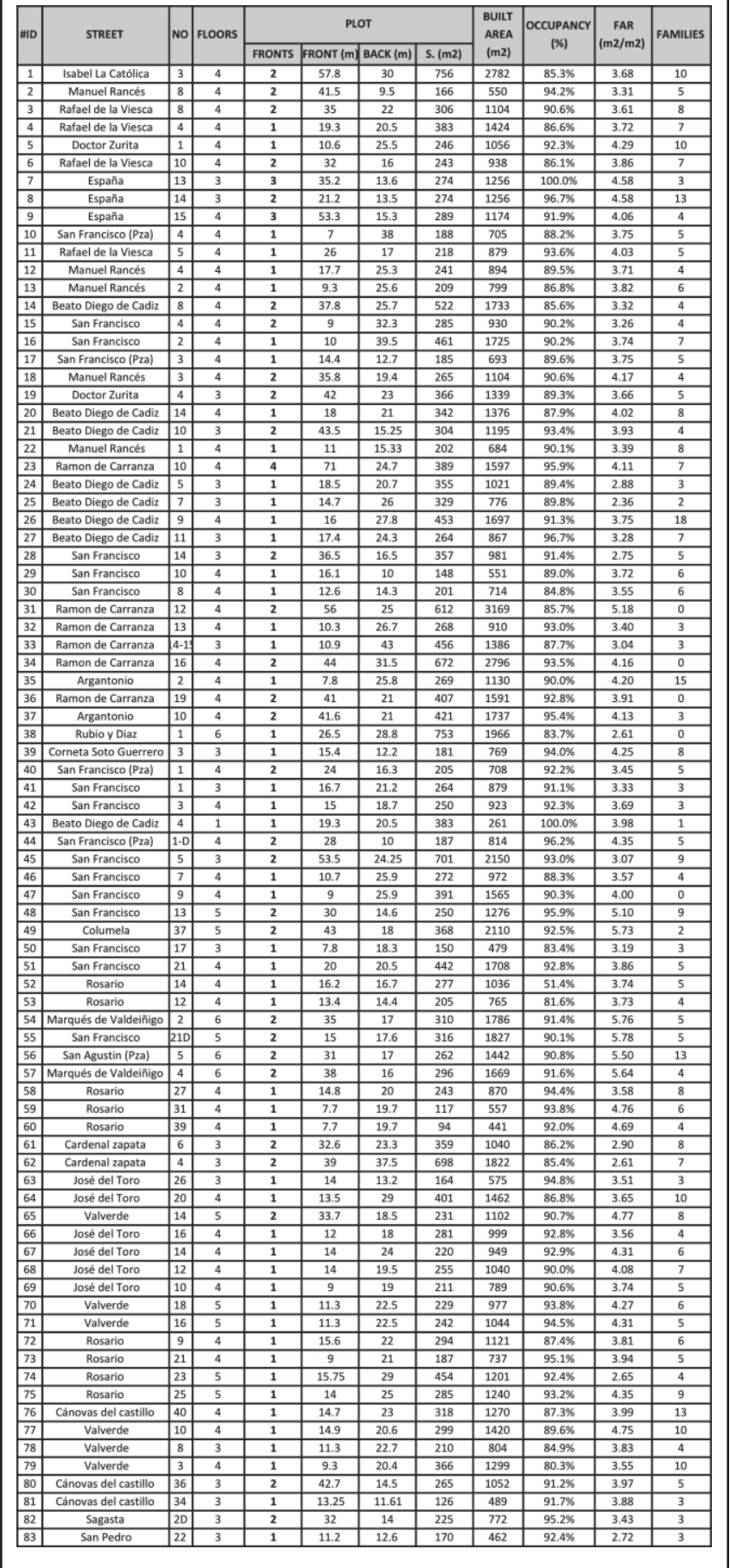


built/m² plot), number of floors.

Location and disposition of stairs and patios (Table 3): These elements organize the connection between the building and the exterior, as well as the internal circulations. A prototypical spatial sequence, common for all houses, comprises a centred entrance that leads to the central patio, which is also attached to the main stairs; secondary patios are to be found disjointed from this ensemble. Taking as a reference point the main façade and looking inwards, the following variables are analysed. For the main patio: Bay where it is located; position of the patio regarding the plot shape, making a distinction between centred with respect to the frontage or sided (attached to the party wall); area of the central patio $\left(\mathrm{m}^{2}\right)$. Regarding the stairs, they are analysed in terms of: Bay where they are located; relative position with respect to the central patio. Secondary patios appear randomly in variegated ways and in different numbers, so the most representative variable to be analysed is their average surface.
Thirdly, the approximate date of construction for the surveyed properties is shown in Table 4. According to available literature and former research by the authors, as this area was developed in the early $16^{\text {th }} \mathrm{C}$ and consistently reformed until $19^{\text {th }} \mathrm{C}$, the analysed time span ranges from 1600 to 1900.

Lastly, in order to clarify the relation of these types with the dimensions of the available plot, a scatter chart (Fig. 5) has been composed depicting the relation between frontage and depth of the available plot area.

Characteristics of house types are as follows.

(1) Plot area: Type A features the lowest average values for plots with IV (subtype A1) and V+ bays (subtype A2), as it encompasses only 2 bays in the frontage. Type B shows the same tendency as type A, but depicting higher values for the three considered subtypes (B1, B2 and B3), as it encompasses 3 bays in the façade. It is evident that plots with 2 fronts (type C) have a greater area for the same number of bays than their counterparts with one front.

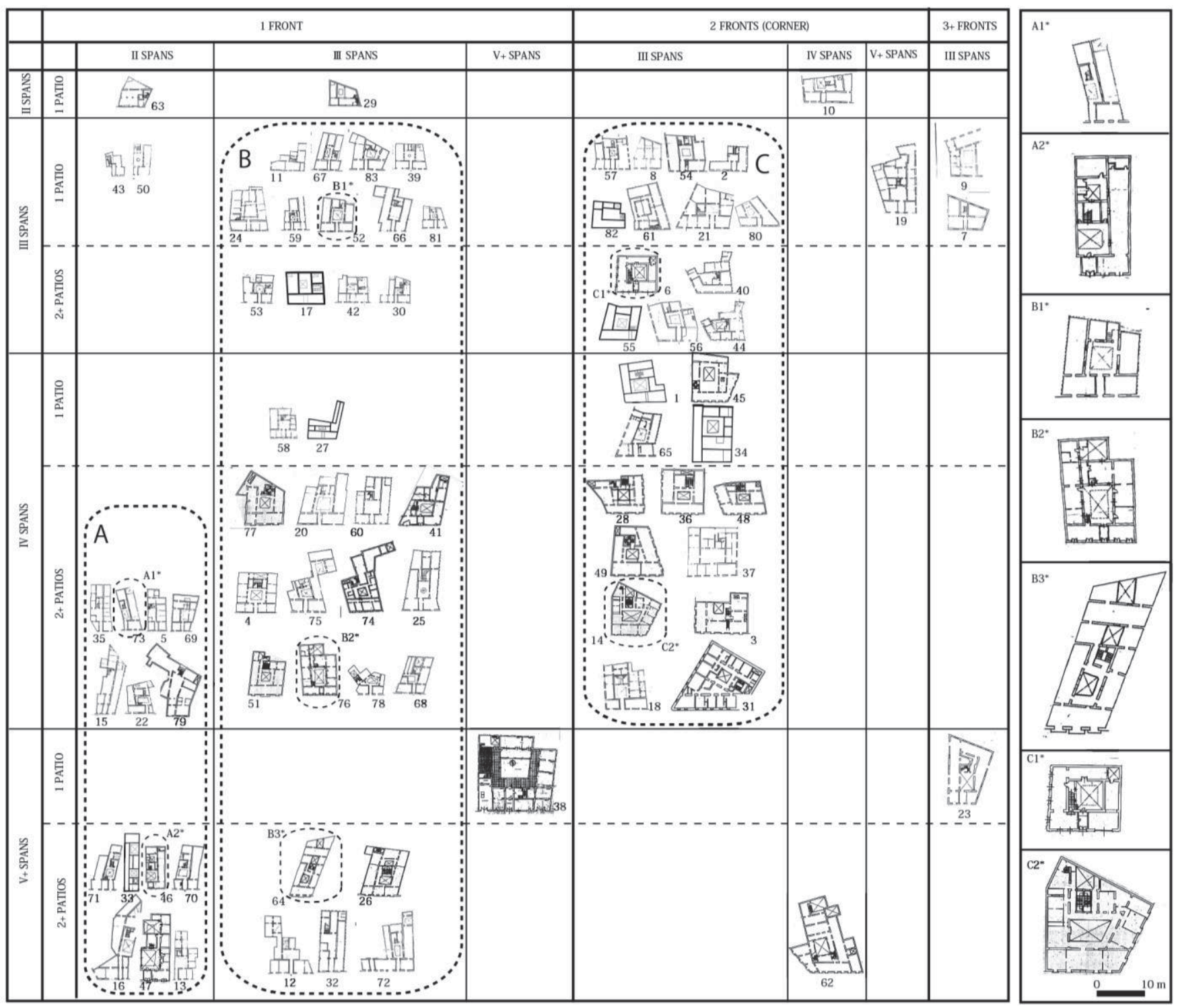

Fig. 4 Classification of House Plan 
Subtypes $\mathrm{C} 1$ and $\mathrm{C} 2$ show the same tendency, the greater the number of spans, the bigger the plot area; also, this type has higher figures, due to the existence of 2 available fronts. In brief, given a frontage with 2 or 3 spans, plot area rises in parallel with depth of the plot.

(2) Built area: Similar tendency as in point 1 can be observed. Given a fixed building frontage, built area is increased in parallel with depth of the plot. For the same number of bays, type A exhibits the lowest figures, type B intermediate values and type $\mathrm{C}$ the highest ones, as a consequence of having two frontages.

(3) Occupancy: All types present very high occupancy rates, ranging around 90\%. No distinction has been found regarding each subtype, which means that this variable bears no relation with the plot area or the number of spans. In other words, high density is a clear objective for all types.

(4) Floor to area ratio (FAR): This point is ought to be understood together with the former. Despite slight oscillations can be remarked, types A, B and C, with their respective subtypes, feature FAR around 4 . These figures can be considered very high, and also independent from the plot area and the number of spans. Again, this high FAR reveals a strong willing of profiting the maximum from the plot, no matter its size, location or shape.

(5) Number of floors: No differences can be made between the three groups and their subdivisions. A, B and C show an average value around 4 floors, which is a constant in this urban tissue for every surveyed property.

(6) Position of the central patio: For all types and subtypes the predominant location of the main patio is found at the second bay. Regarding its position with respect to the layout of the plot, type A has predominantly sided patios, as it has only two bays; types $\mathrm{B}$ and $\mathrm{C}$ feature predominantly centred patios.

(7) Surface of the main and additional patios. These two variables ought to be understood together. Surface of the main patio increases in parallel with the depth of the plot for all subtypes; however, subtype B3 shows an average area for the main patio lower than subtypes B1 and B2, at the expense of bigger secondary patios. This means that central patios have an upper limit from which their surface remains constant, and additional open surface is possible due to secondary patios.

(8) Position of the stairs. Globally, stairs are fundamentally placed in the $3^{\text {rd }}$ span, and centred with respect to the main patio, composing in this way the aforementioned characteristic spatial composition, together with the central patio. However, subtype B1 shows an equal distribution between the $2^{\text {nd }}$ and $3^{\text {rd }}$ bay; this fact matches the predominant disposition of stairs with respect to the main patio, which in this case is equally distributed between centred and sided position. Making a picture,

Table 2 Building parameters. Average values

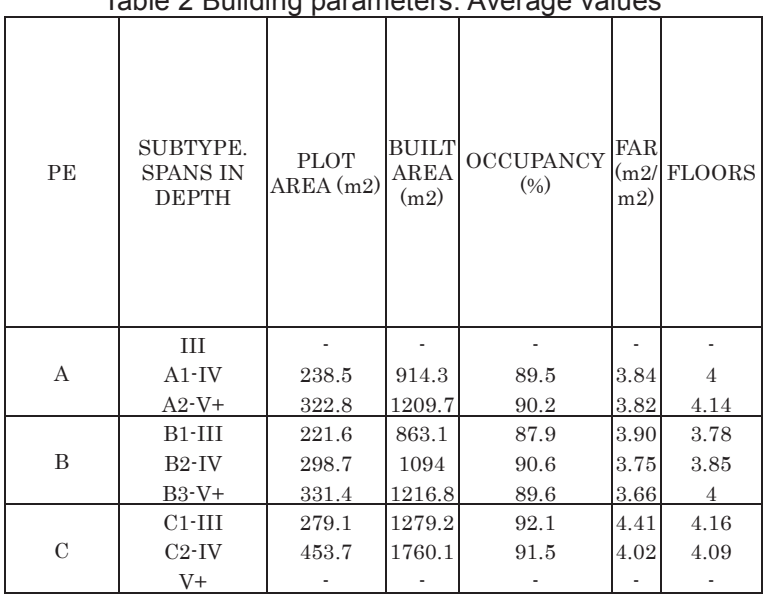

Table 3 Building elements. Patios and stairs.

\begin{tabular}{|c|c|c|c|c|c|c|c|c|c|c|c|c|c|}
\hline \multirow{3}{*}{\multicolumn{2}{|c|}{$\begin{array}{c}\text { TYPE } \\
\text { SUBTYPE }\end{array}$}} & \multicolumn{5}{|c|}{ CENTRAL PATIO } & \multirow{3}{*}{$\begin{array}{c}\text { OTHER } \\
\text { PATIOS } \\
\text { SURF } \\
(\mathrm{m} 2)\end{array}$} & \multicolumn{6}{|c|}{ STAIRS } \\
\hline & & \multicolumn{2}{|c|}{\begin{tabular}{|c} 
SPAN \\
LOCATI \\
ON \\
$(\%)$
\end{tabular}} & \multicolumn{2}{|c|}{$\begin{array}{l}\text { Centred } \\
\text { (C) }(\%) \\
\text { Side } \\
(\mathrm{S})(\%)\end{array}$} & \multirow[t]{2}{*}{$\begin{array}{c}\text { SURF } \\
(\mathrm{m} 2)\end{array}$} & & \multicolumn{4}{|c|}{$\begin{array}{c}\text { SPAN } \\
\text { LOCATION } \\
(\%)\end{array}$} & \multicolumn{2}{|c|}{$\begin{array}{c}\text { Centred } \\
\text { (C) }(\%) \\
\text { Side } \\
(\mathrm{S})(\%)\end{array}$} \\
\hline & & $2 \mathrm{dn}$ & $3 \mathrm{rd}$ & $\mathrm{C}$ & $\mathrm{S}$ & & & $1 \mathrm{st}$ & $2 \mathrm{dn}$ & $3 \mathrm{rd}$ & 4 th & $\mathrm{C}$ & $\mathrm{S}$ \\
\hline A & \begin{tabular}{|l}
$\mathrm{A} 1$ \\
$\mathrm{~A} 2$
\end{tabular} & $\begin{array}{c}100 \\
85\end{array}$ & $\begin{array}{c}- \\
0 \\
15\end{array}$ & $\begin{array}{l}- \\
0 \\
0\end{array}$ & $\begin{array}{c}- \\
100 \\
100\end{array}$ & $\begin{array}{c}- \\
15 \\
19\end{array}$ & $\begin{array}{c}- \\
11.94 \\
13.23\end{array}$ & $\begin{array}{l}0 \\
0\end{array}$ & $\begin{array}{c}- \\
15 \\
0\end{array}$ & $\begin{array}{l}- \\
85 \\
85\end{array}$ & $\begin{array}{c}0 \\
15\end{array}$ & $\begin{array}{c}- \\
72 \\
100\end{array}$ & $\begin{array}{c}- \\
28 \\
0\end{array}$ \\
\hline B & $\begin{array}{l}\text { B1 } \\
\text { B2 } \\
\text { B3 } \\
\end{array}$ & $\begin{array}{c}100 \\
100 \\
80 \\
\end{array}$ & \begin{tabular}{|c|}
0 \\
0 \\
20 \\
\end{tabular} & \begin{tabular}{|c|}
93 \\
100 \\
80 \\
\end{tabular} & \begin{tabular}{|c|}
7 \\
0 \\
20 \\
\end{tabular} & \begin{tabular}{|l|}
14.95 \\
18.34 \\
14.73 \\
\end{tabular} & $\begin{array}{c}5.22 \\
9.8 \\
19.94 \\
\end{array}$ & $\begin{array}{l}0 \\
0 \\
0 \\
\end{array}$ & $\begin{array}{c}50 \\
7 \\
0 \\
\end{array}$ & $\begin{array}{l}50 \\
93 \\
80 \\
\end{array}$ & $\begin{array}{c}0 \\
0 \\
20 \\
\end{array}$ & \begin{tabular}{|l|}
50 \\
86 \\
60 \\
\end{tabular} & $\begin{array}{l}50 \\
14 \\
40 \\
\end{array}$ \\
\hline $\mathrm{C}$ & \begin{tabular}{|l|}
$\mathrm{C} 1$ \\
$\mathrm{C} 2$
\end{tabular} & $\begin{array}{c}100 \\
91 \\
-\end{array}$ & $\begin{array}{l}0 \\
9 \\
-\end{array}$ & $\begin{array}{c}92 \\
100\end{array}$ & $\begin{array}{l}8 \\
0 \\
-\end{array}$ & $\begin{array}{l}17.80 \\
29.42\end{array}$ & $\begin{array}{c}6.61 \\
11.11 \\
.\end{array}$ & $\begin{array}{l}8 \\
0 \\
-\end{array}$ & $\begin{array}{l}33 \\
18\end{array}$ & $\begin{array}{l}59 \\
82 \\
-\end{array}$ & \begin{tabular}{|l}
0 \\
0
\end{tabular} & \begin{tabular}{|l|}
50 \\
50
\end{tabular} & $\begin{array}{l}50 \\
50\end{array}$ \\
\hline
\end{tabular}

\begin{tabular}{|c|c|c|c|c|}
\multicolumn{5}{c}{ Table 4 Date of construction } \\
\hline \multirow{3}{*}{ TYPE } & $\begin{array}{c}\text { SUBTYPE } \\
\text { SPANS } \\
\text { IN DEPTH }\end{array}$ & $1600-1700$ & $1700-1800$ & $1800-1900$ \\
& & & & \\
\hline \multirow{3}{*}{ Type A } & III & - & - & - \\
& A1-IV & $0 \%$ & $72 \%$ & $28 \%$ \\
& A2-V+ & $14 \%$ & $43 \%$ & $43 \%$ \\
\hline \multirow{3}{*}{ Type B } & B1-III & $0 \%$ & $86 \%$ & $14 \%$ \\
& B2-IV & $7 \%$ & $50 \%$ & $43 \%$ \\
& B3-V+ & $0 \%$ & $60 \%$ & $40 \%$ \\
\hline \multirow{3}{*}{ Type C } & C1-III & $16 \%$ & $41 \%$ & $43 \%$ \\
& C2-IV & $9 \%$ & $41 \%$ & $50 \%$ \\
\hline
\end{tabular}

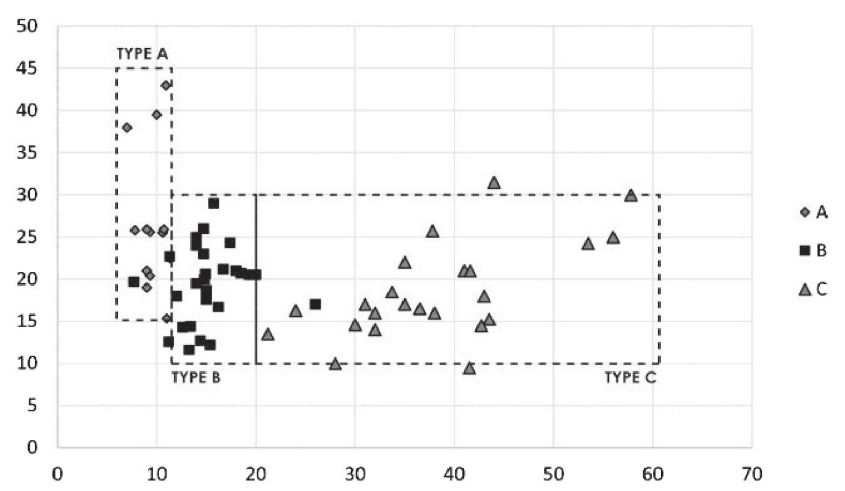

Fig. 5 Plot frontage (X-axis) and plot depth (Y-axis). 


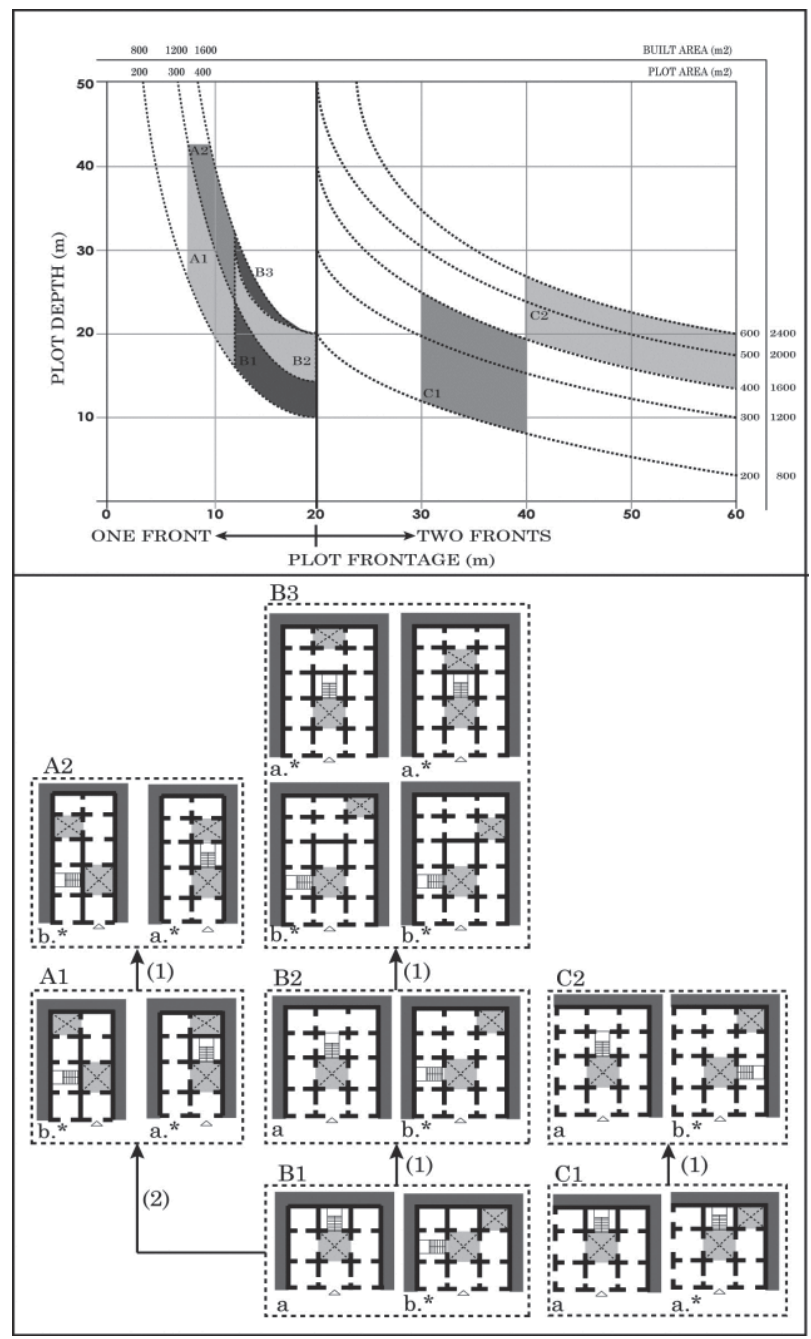

Fig. 6 Formation of house types.

and joining points 7 and 5, a spatial system composed by entrance, central patio and stairs can be devised for all types and subtypes.

(9) Date of construction: Despite that this area was developed during XVII Century, this urban tissue was erected in the $18^{\text {th }}$ and $19^{\text {th }}$ Century by means of a profound urban renovation; only very few items have be found to date back from the XVII Century, and no items were erected after 1900. For all types, items are distributed mainly amongst the $18^{\text {th }} \mathrm{C}$ and the 19 thC; this time span, barely 200 years, reveals that all types are produced in parallel, in a very well defined chronological context. That, also, gives a hint about the formation process, suggesting that instead of a chronological evolution of several types, a formal evolution of a given type or subtype is found in this case.

(10) Relation between types, frontage and depth of plots (Fig. 5). Scattered data for the 83 surveyed properties shows three tendencies that bear close relation with types A, B and C. In this figure, the total length of the frontage has been taken into account. Types A, B and C can be placed in definite ranges, with relation to frontage and plot depth. As types $\mathrm{A}$ and $\mathrm{B}$ have only one frontage, their data is more concentrated in the $\mathrm{X}$ axis; type $\mathrm{C}$, with two frontages, present more scattered data.

(11) A clear division between plots with one frontage and two frontages can be established in $20 \mathrm{~m}$, which correspond to the classical composition of 3 spans in the front, with a centred entrance and two spans at both sides. Leftwards, types A and B are to be found, and rightwards type C. Type A features narrow frontages between 7 and 11 metres (only 2 spans), and very variable plot depths, between 15 and $45 \mathrm{~m}$. Type $\mathrm{B}$ shows longer fronts between 11 and $20 \mathrm{~m}$ (3 spans) and more compact data regarding plot depth, between 11 and $20 \mathrm{~m}$. Type $\mathrm{C}$, for its part, is very flexible regarding its frontage, with data varying between 20 and $60 \mathrm{~m}$; plot depth is found to be similar to type B.

4. Considerations on interrelations between house typesformation and transformation of house types.

According to the data analysis, the following points are concluded in terms of building morphology (Fig. 6).

(1) As for the relationship between date of building and house type, we cannot find any significant relation. Basic spatial arrangements of all types are based on almost the same spatial structure, which consists of entrance, central patio with attached stairs. As previous authors' thesis ${ }^{21)}$ say, this spatial system is traced back to the origin, that is, the date of foundation of Cadiz. It is documented that plots in the $16^{\text {th }} \mathrm{C}$ would be around $15 \times 17$ varas (around $200 \mathrm{~m}^{2}$ ). Based on this document, it can be supposed that subtypes B1 and $\mathrm{C} 1$ have existed from the foundation and are the original layout, for 1 front house type and 2 front house types respectively. We cannot point out chronological evolution as for house plan; instead, it can be said that the very formal plan, a well-established and standardised model of house plan, had been adopted in the beginning of its foundation. It can be supposed that the original standard plan had been transformed in the process of adaptation to the plot conditions during these 200 years (Fig. 6).

1.) Adapting the original type to the plots with various sizes, by increasing plot depth (Fig. 6 (1)) and reducing plot frontage (Fig. 6 (2)).

2.) Making variations in the internal arrangement of the elements that organize the type, that is, the ensemble entrance-patio-stairs. For each subtype, two sub-subtypes are distinguished, i.e. (a) aligned entrance-patio-stairs, (b) aligned entrance-patio and sided stairs. We can find these two sub-subtypes spatial system in all types and subtypes.

3.) Adding auxiliary patios in a variety of positions (*). No clear organization can be devised for them. 
(2) Average values for occupancy rates (around 90\%), number of floors (around 4) and FAR (around 4) are common for all types, which indicates that this transformation process pursued very high built densities in order to gain the maximum volume to the scarce available land.

(3) As a consequence of this process, types A, B and C, and their subtypes can be divided attending at the plot dimensions (X-axis, Y-axis), the plot area and the built area. $20 \mathrm{~m}$ marks the frontier between plots with one and two frontages. For each combination of frontage and depth, curves depicting plot area and built area are composed; as FAR is constant around 4, for each given plot, built area is to be devised multiplying the former by 4 . This allows establishing areas (shaded in tones of grey) where predominant parameters for resulting types can be clarified.

(4) Regarding building elements (ensemble entrance-patio-stairs), for each type and subtype, the transformation process has produced a rigid scheme. The main patio is to be found in the second bay for all types, predominantly centred, except for type A, where it is predominantly sided. The only variation of the stairs consists on placing it centred or sided with respect to the patio. Secondary patios are distributed randomly without any fixed arrangement, being an aid for additional lighting and ventilation.

(5) During 200 years, all types developed a common pattern regarding their formation: A system for obtaining the maximum profit from scarce land. For any given plot, the original type (C1 and B1) expands or contracts its structural grid to adapt to any shape. Then, this grid is extruded vertically to reach a maximum building density (4 floors, occupancy 90\%, FAR 4) and the ensemble entrance-stairs-patio accommodate in this frame, with a fixed layout. This foretells that all types adopt a standardised spatial arrangement in terms of building morphology.

As Table 1 (the rightest column) shows, many families (maximum 18 families) live in one house building at present although 4 houses are unoccupied, which shows the courtyard types has flexibility to accept various families and family types.

\section{Acknowledgments.}

The authors would like to thank Arch. Carlos Rubio Bellido from University of Seville and Arch. Antonio Galindo Riaño from the city planning office of Cadiz for its indispensable support in the fieldwork and also in the elaboration of this research.

\section{Notes}

*1) Visited on January 2015 to compile a digital photographic archive of available material.

\section{References}

1) Malo de Molina J, Jimenez mata J. Guia de arquitectura de Cadiz. Colegio oficial de arquitectos de Cadiz. 1995.

2) Suárez-Canton Huertas, Miguel: La casa gaditana: Análisis de un proceso de evolución y creación tipológica, Doctoral Thesis, Seville,
1996.3.

3) Rubio Bellido C. Valores ambientales de la arquitectura histórica en la ciudad de Cadiz. Estrategias para la rehabilitación. Doctoral Thesis. Sevilla. 2014.11.

4) Falcón Márquez, Teodoro, Torcuato Benjumeda y la arquitectura neoclásica en Cádiz, Instituto de Estudios Gaditanos. 1974.

5) Ruiz Nieto-Guerrero, $M^{a}$ del Pilar, Historia urbana de Cádiz. Génesis y formación de una ciudad moderna, Caja San Fernando. 1999.

6) Rubio-Bellido, Carlos, Galindo Riaño, José Antonio: The fortifications in the town planning of Cadiz, Subcatálogo de edificaciones protegidas, PGOU de Cádiz, 2011.9.

7) VV.AA: Plan General de Ordenación Urbana (PGOU) de Cádiz, 2011.9..

8) Spanish cadastral database available online at the Ministry of Finance website. 2015.1.

9) Historical archives of the city of Cadiz. Catalogue of building plans $\left(18^{\text {th }} \mathrm{C}-20^{\text {th }} \mathrm{C}\right)$. Available on paper format, consulted in 2015.1.

10) Digitalized maps and plans available at Spanish Ministry of Culture and Education, 2014.9.

11) Digitalized maps and plans available at Institut Geográphic de Catalunya, 2014.10.

12) Rojas Vaca, Maria Dolores. Los escribanos del concejo de Cadiz. (1557-1607). University of Sevilla.

13) Rojas Vaca, Maria Dolores. Una escribania publica gaditana en el el S. XVI. Universidad de Cadiz, servicio de publicaciones. 1994.

14) Falcón Márquez, Teodoro: Iconografía: territorio y ciudad en el Cádiz del S. XVI. Trocadero, revista de historia moderna y contemporánea, Vol 16, pp 501-506, 2003.6.

15) De Castro, Adolfo. Historia de Cadiz y su provincia. Cadiz, 1858.

16) Castro, Adolfo de: Nombres antiguos de las calles y plazas de Cádiz sus orígenes, sus cambios sucesos notables ocurridos en ellas, idea de las antiguas costumbres locales por un individuo de la Academia Española de Arqueología, Cádiz, 1857.

17) Del Pozo y Barajas, Alfonso. Sevilla Elementos de análisis urbano. Universidad de Sevilla. Secretariado de publicaciones IUCC. 2003.

1 Among 88 items, 2 were excluded as they are not residential properties, a church and its annex (Fig.2.*1 and *2); 3 properties could not be accessed as they were in a state of ruin.

\section{和文要約}

本論文は、スペイン、カディスの旧市街のサン・フランシスコ地 区の住居類型について、住居類型間の関係（原型と変化型）につい て明らかにすることを目的としている。地区は、カディス市の歴史 文化地区に指定され、22 の街区、224の建築物によって構成されて いる。臨地調查は、カディス市とともに J.A. プリドアルカスが 2009 年のほぼ一年にわたって行ったもので、8 8 軒（分析対象とし たのは 83 軒）の実測およびヒヤリングが中心である。

住居の類型化は、平面形に着目し、ファサードの幅 (スパン数) と奥行 (スパン数)、パティオの数、階段の位置を分類の軸にした。 大きく 3 つに類型化されるが、建設年代に大きな差は見られない。 中央に中庭をもつ極めて形式的な類型（B1, C1）が 16 世紀に建設さ れていることから、当初から 4 階建の極めて高密度の居住形式が採 用されてきたことがわかる。現在、最大 18 家族が居住するなど様々 な家族が居住している。4層中庭式住居の基本型の柔軟性を示して いる。本論文は、南スペインの都市とは異なる住居類型による都市 組織のあり方を明らかにする大きな意義を有している。

(2015 年 5 月 7 日原稿受理, 2015 年 8 月 24 日採用決定 